\title{
The Roles of the University of Tennessee Gardens in a Public Horticulture Teaching Program
}

Susan L. H amilton

AdDITIONAL INDEX wORDs. education, teaching methods, gardening, college campus, curriculum

Summary. The U niversity of T ennessee's undergraduate and graduate public horticulture concentrations are new programs designed to prepare individuals for careers in public horticulture that emphasize people and their education and enjoyment of plants. These new programs could not exist without the educational resources of the university's gardens. The gardens play a variety of roles in supporting faculty, undergraduate, and graduate students in these programs. The gardens serve as an outdoor laboratory and classroom and provide on-campus opportunities for the following teaching and learning activities: plant identification; plant photography; garden design; plant use; garden maintenance internships; special problem topics (e.g., production of annual variety trials, planting and labeling trials, writing garden literature, and creating interpretive displays); mapping and cataloging plants; and garden writing. 0 nly through a university-based garden could opportunities to engage students in such meaningful learning experiences occur providing them with the competitive edge for entering the public horticulture field.

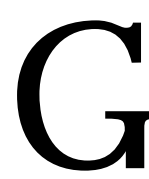

ardening has grown to be one of the most popular hobbies in the U nited States ( $N$ ational Gardening Association, 1999). Peak interest in gardening has created an increased demand for professionals who have both horticulture and educational expertise (M orin, 1998). N ever before have there been such outstanding career opportunities in public horticulture where emphasis is on people and their education and enjoyment of plants. Public horticulture is a growing facet of the industry which includes teachers; extension agents and specialists; professional garden writers; photojournalists, editors and publication managers; city or urban horticulturists; directors of botanical gardens, arboretums, parks, or cemeteries; educational directors; horticulture therapists; and public garden curators and plant collection managers. There is increased demand on colleges and universities to produce professionals who will provide leadership in this growing segment of horticulture (Bradley, 1998; Rakow, 1998; Swasey, 1998; Wott, 1998).

\footnotetext{
U niversity of Tennessee, D epartment of O rnamental H orticulture and L andscape D esign, P.O. Box 1071, Knoxville, TN 37901. The cost of publishing this paper was defrayed in part by the payment of page charges. U nder postal regulations, this paper therefore must be hereby marked advertisement solely to indicate this fact.
}

${ }^{1}$ Assistant professor, U niversity of Tennessee Institute of Agriculture. 
In response, TheU niversity of T ennessee's (UT) D epartment of Ornamental H orticulture and Landscape D esign (O H LD) recently created a concentration in public horticulture within the undergraduate and graduate curricula (Albrecht and $\mathrm{H}$ amilton, 1998). The concentration requires a core curriculum in basic horticulture combined with elective courses in areas including journalism, photography, information sciences, human resource development, grant writing and project implementation, art \& museum science, education, curriculum development, public administration, public relations, adult education, extension education, child psychology, adult development, community planning and development, and program planning. Within the public horticulture concentration, undergraduate students select 20 credit hours while graduate students select 22 credit hours from a menu of those electives which support their public horticultureinterests. Since the concentration was launched in the fall semester of 1998, thirty-six undergraduate and six graduate students have enrolled. For details of the concentration, visit the UT Website (Augé, 1999). In addition to courses outside the UT horticulture curricula, the $U$ niversity of T ennessee I nstitute of Agriculture (U TIA) Gardens have been a valuable resource in supporting the public horticulture concentration. The9-acre(3.6-ha) gardensare located on the UT Knoxville Experiment Station adjacent to the agriculture campus and are open free-of-charge to the public during daylight hours. An estimated 10,000 visitors go through the gardens each year. Since the gardens are relatively small in size, there is not an operating budget separate from the experiment station. Contributed monies, $\$ 53,000$ on average annually, areprovided through afriendssupport group of over 500 members and through revenues generated by thegardens' annual field variety trial program. These monies provide for student internships, educational signs and literature, and plant collection development. In a variety of ways, the gardens support teaching and research faculty aswell asundergraduateand graduatestudentswho arepart of theU T public horticulture program.

\section{Faculty support}

TheU TIA G ardenshavebeen a convenient resource in teaching the required plant material courses in the public horticulture concentration (Table 1). Collections of 800 woody and 3500 herbaceous plant taxa allow for an on-campus, outdoor learning laboratory. Plant collections for plant identification courses no longer need to bestudied from dry mounts, cut specimens in jars or vases, or potted containers in greenhouses where they sometimes become pot-bound, stressed, or insect and disease infested. U sing the UTIA Gardens, students learn to identify plants as they appear in a real world setting throughout the year's course of development. Students have the option of visiting the gardens anytime under changing seasons and environmental conditions and do not have to rely on classroom and greenhouse accessibility. The gardens provide instructors with fresh plant samples for identification exams which may be gathered 1 to 2 $\mathrm{h}$ beforehand so as to maintain high quality samples for classroom testing.

The U TIA G ardens have been designed by faculty to teach and demonstrate plant use, garden design, and landscape construction; all concepts in classes required in the public horticulture curricula. Brick paths and patios, arbors, fences, trellises, bowers, and an amphitheater, all built by students in landscape construction courses, constitute the hardscapes around which the gardens have evolved. A 200-ft (61-m) long perennial border and annual field trials including All-America selections and Fleuroselect winners, allow for the demonstration of ornamental herbaceous plants. Trees, shrubs, groundcovers and vines accentuate the garden's hardscapes, demonstrating their landscape value and use. Appropriately placed benches and garden statuary illustrate the value of accents and focal points.

Faculty who teach plant identification, plant use, and garden design often use photographic slides to support their lecture material.
Fig. 1. U ndergraduate students planting a pansy and bulb garden as a class project in the $U$ niversity of T ennessee I nstitute of Agriculture G ardens.

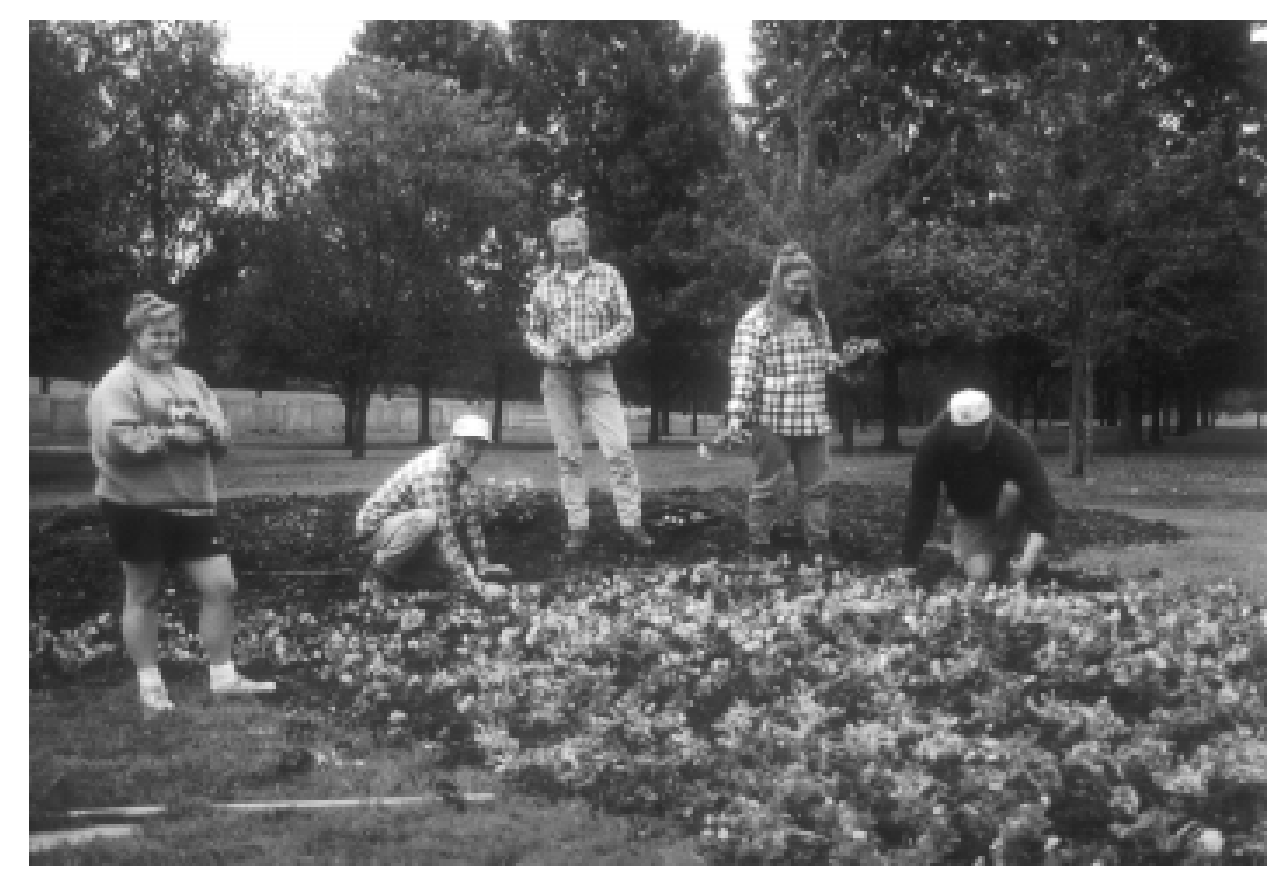




\begin{abstract}
Faculty support
Teaching plant identification [O H LD 220 Basic Landscape Plants ( 3 h) ; O H LD 320 Plant materials ( 2 h)]

Teaching plant use and garden design [O H LD 280 Fundamentals of Landscape D esign ( 3 h); O H LD 390 Fall H erbaceous O rnamental Plants (3 h); O H LD 391 Spring H erbaceous O rnamental Plants (3 h)]

Teaching landscape construction [O H LD 350 Basic L andscape C onstruction ( 3 h); O H L D 360 Practicum in L andscape C onstruction (3 h); OH LD 450 Specialty Landscape Construction (3 h)]

Photographic library source

O utdoor site for class labs and projects [O H LD 493 Individual Problem Study (1-3 h)]

U ndergraduate support

Garden maintenance internship credit [O H LD 492 Internship (1-3 h); O H LD 499 Capstone Experience (3 h)]

Special problem topics credit [O H LD 493 Individual Problem Study (1-3 h)] (production of field trials, planting and labeling trials, writing garden literature, and creating interpretive displays)

$\mathrm{G}$ raduate support

$M$ apping and cataloging plants

Garden docent

L eading educational workshops

D esigning and installing a garden

Evaluating and photographing trials

Garden curator internship

Writing garden newsletter articles

N onhorticulture course projects [Art 481 M useology I: M useums, Purpose and Function (3 h); Art 482 M useology II: Exhibition Planning and Installation ( $3 \mathrm{~h}$ ); I nformation Resources: Selection, Acquisition, and Evaluation ( 3 h); Art M edia 431 Photography III (3-6 h); Botany 507 Biological Illustration (3 h)].
\end{abstract}

${ }^{2}$ C ourse prefix, OH LD $=0$ rnamental $\mathrm{H}$ orticulture and L andscape D esign.

ySemester credit hours, 1 credit = one 50-min lecture or one 2- to 3-h laboratory.

$\mathrm{H}$ aving these gardens providesa convenient and valuable resource for building a photographic library. Photographs from the campus gardens, which studentscan visit and relateto, have proven to bean excellent way to document and teach plant and cultivar performance as well as seasonal changes and variability in a garden.

The U TI A Gardensarean asset to the public horticulture teaching program by providing a hands-on learning site for class labs and projects. 0 ne proven example has a class design and plant afall-through-spring display garden using pansies and bulbs (Fig. 1). The students develop the design, determine color use, calculate required plant number, prepare the soil, and install the garden. Students benefit from learning by doing and observing the results, and taking pride in their contribution to campus aesthetics.

\section{Undergraduate student support}

The U TIA Gardens have proven to be a valuable educational resource for earning academic credit. The gardens, on average, generate $30 \mathrm{~h}$ of academic credit per year for public horticulture students through a variety of courses and projects (Table 1). Students seeking academic credit for special problem topics or internships have been able to do so by participating in the maintenance of the gardens. Students are involved in all garden maintenance activities and are given specific responsibilities. Thisgivesthem the opportunity to see first hand the work and challenges involved in maintaining a public garden.

Academic credit has been given for students participating in the summer annual variety trial program through transplant production in the greenhouses, installation, and subsequent evaluation of the trials in the UTIA Gardens. Students fully participate in the interpretive process by designing and authoring 'point-of-interest' signs, garden guides and literature, and other displays for the gardens.

\section{Graduate student support}

The UTIA Gardens have proven to beavaluableeducational resourcefor graduate students preparing for the public horticulture industry (Table 1 ). Four to five graduate students each semester have been involved in various research and educational projects and, like undergraduate students, earn academic credit for their work. The gardens, on average, generate $24 \mathrm{~h}$ of academic credit per year for public horticulture graduate students. Examples of work done by students include computer mapping, serving as a docent, leading a summer camp for children, designing and installing a new aspect of thegardens, evaluating and photographing field variety trials, cataloguing a particular plant collection, updating and remaking plant labels, supervising maintenance activities, acquiring new plants for the gardens' collections, and writing articles for the Friends of The Gardens newsletter.

The U TIA Gardens are a valuable resource for graduate students desiring experience in theoperation and maintenance of a public garden as well as personnel management. $M$ aintenance and plant acquisition is managed by awarding a competitive curator internship each semester to a graduatestudent seeking such public garden experience. The curator position is part-time for spring and fall semesters and full-time for summer. The curator is expected to provide leadership in all facets of maintenance activities as well as assist visitors and supervise two to three part-time undergraduate students each semester who assist with the gardens' maintenance. As the gardens expand, so will the number of curators each semester. Financial support for internships is provided through the Friends of The Gardens organization and revenues from 
the summer and winter annual variety trial program.

G raduatestudentsmayal so receive academic credit to study and practice garden design in the UTIA Gardens. Past projects have focused on creating new site aspectsor revital izing old plantings. $\mathrm{O} n$ average, half an acre per year is either developed or revitalized. This gradual development has resulted in 5 acres ( 2 ha) being intensely cultivated within the9-acre (3.6-ha) gardenssince 1983 when the gardens were initiated. In this manner, the gardens act as a testing ground for students, enabling them to turn their design visions into reality. This practice not only allows them to see what is right with their designs but their errors as well. After being critiqued by a jury of faculty, two of whom are landscape architects, the design error of one student may be the design project for another. $\mathrm{H}$ aving a site which allows students to trial and test their garden design abilities is a learning opportunity not afforded by most public gardens.

A major task of the U TIA G ardens is herbaceous summer and winter field variety trials. With $>500$ annual variety trials in the summer and 300 in the winter, the task of plant evaluation is monumental. Graduate students assist principal investigatorsin evaluating and documenting plant performance. Students assist in photographing the trials and collecting plant evaluation data(Fig. 2). They help analyze the data to determine the best and the poorest garden performers, and have later gone on to present their resultsat professional, commodity, and public meetings, and have coauthored research reports, extension publications, and trade magazines.

Public horticulture students can al so gain experiencein garden mapping. Asthegardens grow, so has the need for making a permanent record of themany plant collections. O ne faculty member has developed the master plan where graduate students receive credit for mapping various portions of the gardens. Somehavedoneit byhand whereas others have used the latest computer technology. The experience graduate students gain recording and mapping plant collections, particularly with this technology, is an asset to their public horticulture portfolios.

The quarterly Friends of The G ardensnewsletter provides additional opportunitiesforgraduatestudentsto professionally write and publish. Students

contribute variousarticlesrelated to specific plants and activities in the gardens. Students who have been responsible for maintenance and plant acquisition contribute articles which keep readers informed on thelatest eventsand additionsin thegardens. Becausethis activity comes with a byline, it has been an effective method to instill pridein students for their efforts and contributions.

The UTIA Gardens support various outreach programs in which graduate studentsmay participate. $O$ nesuch example is the gardens' volun-

teer program

which allows an intern to advertise volunteer opportunities in the Friends of The $G$ ardensnewsletter and then coordinatevolunteer timeand activities. This has been a succesfful program in helping meet the labor demands of the gardens. Graduate students have also written and submitted a grant application for a youth gardening program and then organized, coordinated, and taught a summer camp program with a local elementary school. Graduate students lead toursand act as docentsfor avariety of special events held in the gardens throughout the year (Fig. 3).

The U TIA Gardens support class projects in non-horticulture graduate courses to accommodate various interests of public horticulture students. For example, in the museum and information science courses, graduate students learn the methods and operations of museums. Thesestudentshaveused the UTIA Gardensto study, catalogue, and evaluate its various plant collections. $\mathrm{N}$ ot only do studentslearn about collections and cataloguing, but faculty benefit by the data they collect. The collection of 40 different taxa of ornamental
Fig. 2. G raduate students assisting with evaluations of summer variety trials in the University of T ennessee Institute of Agriculture $\mathbf{G}$ ardens.

grasses in the U TIA G ardens had never been catalogued or evaluated. Since a graduatestudent catalogued and evaluated thecollection, taxamissing to complete a comprehensive collection have been identified. The same has been done by another student with the gardens' herb collection.

\section{Conclusion}

The U TIA Gardens are a tremendous value to the UT undergraduate and graduate public horticulture concentration. The variety of teaching and learning activitieshighlighted would not be possible if it were not for the existence of the UTIA Gardens. Providing opportunities for students to test their interests as well as abilities makes the UTIA Gardens an exceptional educational resource. It provides a model testing ground for students considering careers in public horticulture. It plays a 


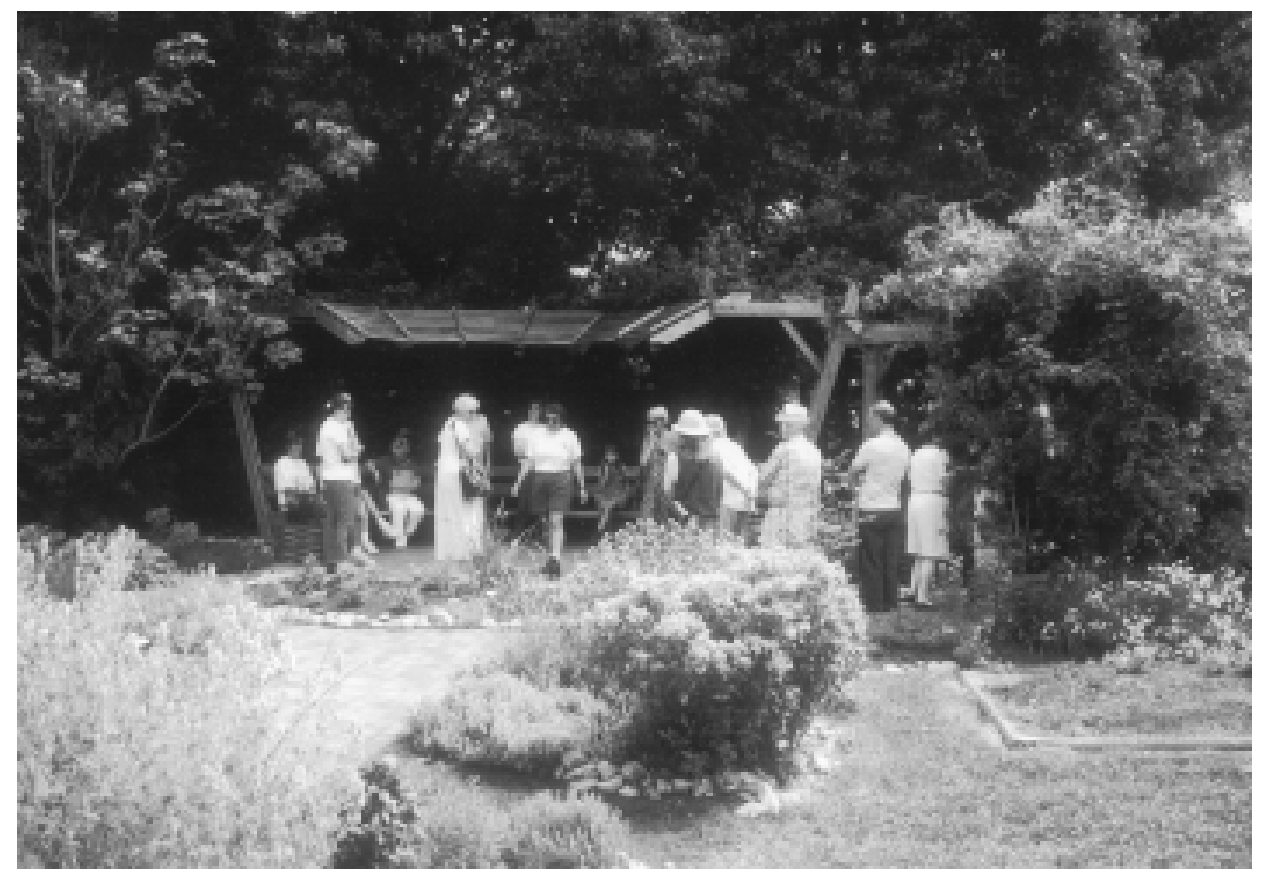

Opportunities will be created to teach and engage students in meaningful learning experiences providing them with the competitiveedgefor entering the public horticulture field.

\section{Literature cited}

Albrecht, M . and S. H amilton. 1998. Public horticulture at the $U$ niversity of Tennessee. Public Garden 13:(4)22-23.

Augé, R. 1999. Public horticulture concentration page. U niv. of Tennessee. 7 July $1999<$ http:/ / o h Id.ag.utk.edu / htm / undrpubl.htm>.

Bradley, J. 1998. The U niversity of Florida public gardens management specialization. Public Garden 13:(4)20-22.

M orin, N . 1998. Cultivating thenext generation of public horticulturepro-

Fig. 3. A graduate student leading a tour of the U niversity of Tennessee Institute of Agriculture G ardens for visitors at the gardens' 1998 Summer $\mathbf{O}$ pen $\mathrm{H}$ ouse. fessionals. Public Garden 13:(4)14.

N ational Gardening Association, 1999. The 199798 National Gardening Survey. B. Butterfield (ed.). 13 M ay 1999. <http:/ / www2.garden.org/ nga/ rsrch/ home.html>.

major rolein preparing and equipping students with theskillsand experiencesthey will need to be qualified and competitive for assuming positions in public horticulture. The UT public horticulture concentration is a new program but with the support of the UTIA Gardens, it has indications of success. As the UTIA Gardens continue to evolve and expand, so will the UT public horticulture concentration.
Rakow, D. 1998. Professional training in public garden management launched at Cornell. Public Garden 13:(4)14-15.

Swasey, J. 1998. The Longwood graduate program. Public Garden 13:(4)19-20.

Wott, J. 1998. Arboretum and public garden management programs at the $U$ niversity of $W$ ashington. Public Garden 13:(4)24-25. 